University of Chicago Law School

Chicago Unbound

Journal Articles

Faculty Scholarship

1969

\title{
A Study of the California Penalty Jury in First-Degree-Murder Cases
}

Harry Kalven Jr.

Follow this and additional works at: https://chicagounbound.uchicago.edu/journal_articles

Part of the Law Commons

\section{Recommended Citation}

Harry Kalven, Jr., "A Study of the California Penalty Jury in First-Degree-Murder Cases," 21 Stanford Law Review 1297 (1969).

This Article is brought to you for free and open access by the Faculty Scholarship at Chicago Unbound. It has been accepted for inclusion in Journal Articles by an authorized administrator of Chicago Unbound. For more information, please contact unbound@law.uchicago.edu. 


\section{A Study of the California Penalty Jury in First-Degree-Murder Cases}

Preface

I am grateful to the editors of the Review for their invitation to add a brief word to their study of the jury and the death penalty under California law. There is much in their effort that is a source of excitement and encouragement; there are also some tendencies I find disturbing.

The study is another instance of the quite extraordinary assault being made these days on the problem of the death penalty by the use of empirical inquiry into its operation. In the last decade the controversy over capital punishment has taken a new turn. For years debate had been addressed to the legislature and supplemented by data collected on the issue of whether capital punishment was in fact a deterrent. While the data fell considerably short of compelling proof that capital punishment did not deter, it undoubtedly had its impact on public opinion and had its share in developing the momentum for legislative reform.

The modern attack has been primarily addressed to the courts and to challenge on constitutional grounds. Its focus has shifted from deterrence to the administration of the penalty itself and to the strains it has imposed on legal institutions. Thus there have been studies of whether in operation the death penalty has been administered with racial bias in the South in rape cases, studies of patterns of agreement and disagreement in decisions of jury and judge in death cases, studies of the incidence of executive clemency, studies of death-qualified juries, and the problems for jury selection created by the exclusion of scrupled jurors. To this cluster the present study now adds empirical data on the determinants of jury decisions for or against capital punishment, with special focus on the evenhandedness and rationality with which the penalty is in reality administered. The strategy is not simply to argue policy, but to add an empirical underpinning to the argument; and the objective is not simply to add to our knowledge of the jury or of the death penalty, but to mount a constitutional challenge. Although I shall voice, in a moment, some misgivings about the editors' desire to find the "payoff" for their study in direct constitutional attack, I would here emphasize that the study satisfies two important criteria for significance in the empirical study of legal issues and institutions: continuity and relevance.

The very existence of the note as a product of law-student work is a fact of high importance. It, together with the select company of other recent 
student law review notes based on empirical study, marks a development that may prove as far reaching for legal education and scholarship as the founding of the law review itself. The law review, whatever its current despairs, has proved a remarkable institution in the 75 years or so since volume I, number I, of the Harvard Law Review made its debut. The idea of a learned journal, totally edited and in part written by students, still amazes colleagues in other areas of the university. It has provided a splendid method of "clinical training" for a law-school elite, and a hospitable forum for legal scholarship. American legal education would be very different and much the poorer without it. I belabor these familiar themes because we may be on the brink of another breakthrough in legal scholarship via the law review.

The rapprochement between law and social science has had a fitful and uneven career for over half a century now. The last decade has finally seen a shift from prospectus to concrete work, and we have harvested a small shelf of books reflecting serious and sustained empirical inquiries into law and its institutions. But there remain great puzzles as to how to organize such research ventures, how to recruit personnel to them, and how to fit them into the traditions and rhythms of more traditional legal scholarship. A chief source of these difficulties has been the circumstance that law schools, unlike other graduate areas at a university, do not really have cadres of graduate students to man research. Another source, perhaps, has been the fact that law faculty have essentially been trained in another tradition, and are likely to find the technique, pace, and style of such research somewhat alien. Accordingly, there are many proposals for special interdisciplinary institutes to train law faculty, special courses in methodology to stimulate student interest, creation of special centers at universities for interdisciplinary research, and the devising of strategies for enlivening interest in graduate study in law. But the truth remains that the contemporary momentum for empirical inquiry in law is considerably slowed by the stubborn facts of organization.

It is at this juncture that the law reviews may once again be coming to the rescue of legal education. The young have the energy and the gallantry to gamble; they are less committed to customs of scholarship; they may well be better educated in methodology; today especially they show a deep interest in social reality and hence an appetite for fact. In brief, there is the possibility-which efforts like this study of the death penalty do much to strengthen-that empirical inquiry into legal institutions will prove a "natural" for the student editors of the law reviews and thus make possible the new scholarship on a wide front.

But even as one writes, some sober second thoughts arise. What the lawschool world needs at this time are empirical studies of quality, of intellec- 
tual rigor comparable to that which has gone into professional law study. The ultimate objective, it must always be remembered, is not to revolutionize law but to enrich it, to develop not a competing but a companion discipline for its study. One of the current sicknesses of the law reviews is that so much of the work published is simply mediocre and can be justified mainly as a writing and research exercise for the student. The law reviews, partly because there are so very many of them, run the risk of being instances of a vanity press. The new danger is that we will spawn via the law reviews a mass of ill-digested, uncritical, drab empirical studies that will only confirm the skeptics. The emergence of the law review empirical student note is another indication that what the law-school world needs today is to develop taste in empirical inquiry.

After so many generalities, let me turn briefly to the specific study. The design and the focus of inquiry are simple and coherent. The purpose was to study the performance of the jury in capital cases under the special California procedure in which there is a separate trial on penalty, after guilt has been established. The universe was the cases where this procedure had been used in the interval from $195^{8}$ to 1966 , in which the same jury had decided both guilt and penalty. Since the number of cases in the universe was relatively small and since they were confined to a single state, albeit California, it was possible to collect all cases in the universe, and thus avoid the often troublesome issue of sampling. As a result the study is based on some 238 cases in all in which the death penalty could have been given. In fact it was actually selected by the jury in ro3 of the cases. The study thus surmounts one obvious obstacle to empirical study of the death penalty, namely, the relative infrequency with which it is given today. In The American Jury, for example, where Hans Zeisel and I had the advantage of a large national sample of criminal jury trials, we nevertheless ended up with only 2I cases in which the jury actually voted death.

The research design involved what is known as secondary analysis, that is, the utilization of records and data which are already in existence and require only analysis. Compare again The American Jury, in which we had to generate to a considerable degree our data by having judges tell us how they would have decided these cases had they tried them without a jury. The note writers, in effect, "interviewed" the files and collected information on some 178 items about each case. It is worth noting again that they did not have to wait for capital cases to arise but could utilize past cases.

The study is built on the mass of data generated by having 178 items of information about each of 238 cases. The question they put to their data is a clear one: What accounts for the incidence of the death penalty, which was given in somewhat less than half of the cases in which the jury had the power to give it? 
The force and quality of the answer will depend on two factors: the adequacy of their network of $x 78$ items about the case and the competence of their statistical analysis of the data. I have neither the time nor the competence to attempt such an assessment here, but I would nevertheless offer two quick reactions. First, the choice of who, among those the legislature has made eligible for death, should die must, insofar as it does not altogether defy analysis, depend often on factors of the greatest subtlety, nuances of personality or demeanor. These are precisely the kinds of facts that might well escape the net of an after-the-fact questionnaire. The note writers were admirably diligent and patient in their pursuit of data about each case, but some of the fish must have been too small for their net.

Second, the note writers are quite clear about the essential analytic problem their data pose. It will not be enough simply to run each of the I78 factors against the penalty and see for which the incidence of the death penalties was significantly higher. One cannot so simply approximate the logic of the experiment when one is working retrospectively. For any given factor it cannot be assumed that except for it the cases in which death was or was not given were otherwise the same, so that it represents the only relevant difference between them. The problem then is to control for the interaction of other factors with the factor being tested, so as to avoid what the statistician calls a spurious correlation.

The note tackles this problem by a statistical technique which is beyond my competence and which gives every appearance of having been pursued with rigor. My somewhat unhappy reactions are twofold: First, it is likely that no legal readers of the note will be able to judge the logic of the method; second, it places a great strain on the exposition of the study, a strain the authors do not altogether meet. They simply cannot carry the reader with them in the logical game of analyzing their data. The analysis as reported becomes curiously mechanical, with the computer playing the main role. The tables offered verge on the unreadable and uninteresting. The possibilities of discursive analysis are thus severely curtailed, with a consequent loss of interest. The story can have no plot, and they might just as well have simply given us the list of $x 78$ items and told us which ones the computer reported were independently significant variables. The note may thus mark a major dilemma for us all and for sociology in general. If the statistical techniques are as powerful and economical as they appear, they represent a gain. But the price for the new technology seems to be that humane exposition becomes virtually impossible.

I would suggest also that the authors risk being corrupted somewhat by their passion for turning their findings into constitutional arguments against the death penalty. It keeps them from being speculative enough about the mystery they are inquiring into. They never pause to reflect on 
how extraordinary must be the decision as to who among those eligible for death is to die. They are forced by their practical concerns to emphasize greatly the finding that the jury discriminates between white-collar and blue-collar workers. I am not persuaded that this is an expression of simple class bias and not a reflection of a more subtle concern with personality and character. Moreover, this distracts them from two other points of deep interest. First is the degree to which the jury decisions as to death cannot be explained, which I would like to think is the consequence of society asking an unanswerable question of the jury. Second, they are underimpressed with their extraordinary finding that race plays no role in explaining the incidence of the death penalty. Surely there is embedded in that point a profound secret both about the nature of race prejudice and the nature of law.

But on balance I am delighted by the seriousness, weight, and sophistication of their effort, and I am excited by the happy prospects it stirs up for the future.

Harry Kalven, Jr.*

- A.B. 1935, J.D. 1938, University of Chicago. Professor of Law, University of Chicago Law School. 